\title{
Impact of Migrant Remittances on Health and Education Outcomes in Sub-Saharan Africa
}

\author{
${ }^{1}$ Uzochukwu Amakom, ${ }^{2}$ Chukwunonso Gerald Iheoma \\ Institute for Development Studies, University of Nigeria, Enugu Campus, Enugu, Nigeria \\ African Heritage Institution (AfriHeritage) 54 Nza Street, Independence Layout, Enugu, Nigeria
}

\begin{abstract}
This study investigated the impact of international migrant remittances on health and education outcomes of sub-Saharan African countries using 18 sub-Saharan African countries. To account for endogeneity between remittances and health and education outcomes, the paper constructed two simultaneous equation models estimated using the two-stage-least square (2SLS) technique. Findings reveal that remittances impact positively and significantly on health and education outcomes of selected countries. For every 10 per cent increase in remittances, primary education outcome increases on the average by 4.2 per cent, secondary education outcomes by 8.8 per cent, and health outcome by 1.2 per cent. After accounting for individual country heterogeneity, results confirm that remittances still remain a significant factor in accelerating improvements in health and education outcomes in recipient developing (Sub-Saharan African) countries. Other factors such as per capita income, education expenditure, and health expenditure were found to be significant. Policy implications are that policy makers must develop appropriate incentive for migrants to remit, especially policies influencing the costs and channels of remittances.
\end{abstract}

Keywords: Migrant, Migration, Remittances, Education, Health

\section{Introduction}

Common features of all developing economies are shortages in savings, foreign exchange, government revenue and human capital skills. Traditional and contemporary economic growths theories have identified these variables as major determinants of economic growth and development. However, given the severe inadequacy in the domestic supply of these factors, migrant remittances have been identified as alternative sources of supply of these critical development inputs. Remittances from migrants to their families in developing countries now constitute a significant percentage of household income. These create costless sources of cheap fund needed by recipient household to engage in subsistent agriculture and other non- agricultural investment opportunities that are essential to escaping the poverty trap and improving health and education attainments.

The inflow of migrant remittances can be considered as an indicator of economic benefit of migration as an anti-poverty tool. Over the last few decades, global remittances have grown significantly. According to World Bank (2006), global remittances have increased from about US $\$ 30$ billion annually in the early 1990s to an estimated US \$318 billion in 2007. Significant portion of this fund in directed toward developing countries. In 2005 it was estimated that approximately 500 million people (18 percent of the world's population) were benefiting from remittances. Latin American and the Caribbean, East Asia and the Pacific, and South Asia received the largest shares of international remittances (Adams 2007). According to 2007 estimates, these regions received respectively 25,24 and 18 percents of all official international remittances to developing countries. By contrast, sub-Saharan Africa received less than 5 percent of all official international remittances (Adams, 2007). African migrants sent close to US\$60 billion in remittances. With scarce opportunities at home, the majority of the 120 million recipients in Africa depend on remittances for improved access to health and education services.

An important aspect of the migration and development debate concerns the effect of remittances on educational and health attainments in the migrants' origin countries (Mara, et al, 2012). Remittances are associated with increased household investments in education, entrepreneurship, and health - all of which have a high social return in most circumstances. Studies based on household surveys in El Salvador and Sri Lanka find that children from remittances-receiving households have a lower school drop-out ratio and that these households spend more on private tuition for their children. In Sri Lanka, the children in remittance-receiving households have higher birth weight, reflecting that remittances enable households to afford better health care.

Considering the interaction between remittances on the one hand, and education and health on the other, and given that sub-Saharan Africa receives the least proportion of global remittances, the pertinent questions to ask are: is there any impact of remittances on health and education outcomes in sub-Saharan Africa?, and what is the magnitude of the impact, if any? The attempts to provide empirical answers to these 
questions have created the existence of contrary views. This paper seeks to provide an empirical base for invigorated debate on the impact of remittances on health and education outcomes in sub-Saharan Africa using 18 countries in the region.

The rest of this paper is structured as follows: after the introduction in section one, a brief literature review is attempted in section two. Section three presents the models and estimated results of the paper, while discussion of findings, policy recommendations and conclusions are contained in section four.

\section{Brief Theory of Migration}

\section{Literature Review}

Migration can be viewed from the perspective of structural change theory as propounded by Arthur Lewis. The Lewis model identifies two sectors: a traditional, overpopulated rural subsistence sector characterized by zero marginal labour productivity, and a modern urban industrial sector into which labour from the subsistent sector is gradually transferred. If we take the urban industrial sector to represent advanced economies and the rural subsistence sector to portray low income countries, Lewis model illustrates that as long as developed-country wage is above developing-country average income, migration will occur as employers in advanced economies try to hire cheap and surplus labour from low income countries.

However, the Lewis model is characterized by severe shortcomings: the assumption that the rate of labour transfer and employment creation in the modern sector is proportional to the rate of modern-sector capital accumulation is untenable because capital may be reinvested in more sophisticated laboursaving capital equipment rather than duplicating the existing capital; the assumption of surplus labour in the agrarian countries and full employment in the advanced nations has been confirmed to be untrue by most contemporary research; and the assumption of diminishing returns in the industrialized economies has been found to be inapplicable to development policymaking as there is much evidence indicating that increasing returns prevail in those countries. Following inherent weaknesses of the Lewis model of labour migration from developing to developed countries (rural-urban), the Todaro-Harris model now presents a more realistic theoretical postulation of migration.

Migration is primarily an economic phenomenon, the decision of which is rational for the individual migrant. This decision, according to the Harris-Todaro model, proceeds in response to urban-rural differences in expected income rather than actual earning. The hallmark of the theory is that migrants critically evaluate labour market opportunities available to them in the developing and developed economies (rural and urban sectors) and then choose the one that maximizes their expected gains from migration. In essence, the main assumption underlying the theory is that potential and actual migrants from developing countries compare their expected incomes for a given time horizon in the developed nations (difference between returns and cost of migration) with prevailing average income in their country of origin and migrate if the former exceeds the latter (Todaro and Smith, 2010).

It is important to note that this migration model implicitly assume a full employment or near-full employment. In a full employment situation, the decision to migrate can be solely determined by the desire to secure the highest-paid job wherever it becomes available. Simple economic theory would then suggest that such migration would lead to wage reduction in the emigrating country and wage increase in the immigration through the interaction of the forces of demand and supply.

Unfortunately, such an analysis is not realistic in the context of the institutional and economic framework of most advanced economies. These countries have legal and market barriers that constrain entry into the labour market. Thus, a typical migrant cannot expect to secure a high-paying job immediately. In the case of migrant with relevant skills obtained through higher education, opportunities are much better, and many will find formal jobs relatively quickly. But they constitute only a small proportion of the total migration stream. Consequently, in deciding to migrate, individuals must weigh the probabilities and risks of being unemployed or underemployed for a considerable period of time against the positive developed-developing countries real income differential. The fact that a typical potential migrant who gains a job in advanced countries can expect to earn five times the annual real income in an advanced nation than in a low income country may have weak theoretical implication if the actual probability of his securing the higher-paying job within, say, a one-year period is one chance in five.

In sum, the Harris-Todaro migration model has four basic characteristics: migration is mainly determined by rational consideration of benefit and cost; the decision to migrate depends on expected rather than actual wage differential between developed and developing countries; the probability of obtaining a job is related to developed-country employment rate; and migration rates in excess of developed-country employment rate is possible given the expected income differential between high and low income countries. High unemployment rate in advanced economies are thus as a result of the imbalance of economic opportunities between industrialized and agrarian economies. 
The Harris-Todaro model is relevant to developing countries even if institutional forces do not determine the wage, such as minimum wage. Recent theoretical research on developing-developed country migration has provided evidence that the emergence of high modern-sector wage in advanced economies alongside unemployment in low income countries can also result from market responses to imperfect information, travel requirements, travel cost and other barriers to international migration (Teal, 1996; Bencivenga and Smith, 1997).

\section{Remittance Trends}

Remittances are an important source of income for most developing countries. The trend of remittances has had an important implication for the economies seen both in micro and macro perspective. In microeconomic perspective, remittances directly affect household's income and consumption; whereas in macroeconomic perspective, remittances influence poverty reduction, economic growth, entrepreneurship and financial development (Aggarwal, Kunt, Peria, 2006). However, the micro and macro-economic implications of remittances depend majorly on their trends. Arguably, undue fluctuation in remittances will have a profound negative or positive influence on the receiving economies depending on the direction of the fluctuation, that is, weather it goes upward or downward.

Although data on migrant remittances are extremely difficult to measure for a variety of reasons, available official figures show that recorded remittances constitute nearly two third of foreign direct investment (FDI) flows and more than double official aid flows to developing countries. From 2000 to 2002, Remittances to developing countries increased by 100 percent. Much of this increase occurred in low- and middle-income countries.

Figure 1 shows remittances to selected sub-Saharan African countries in 2007 and 2011. From the table, it can be seen that Senegal, South Africa, Uganda, Kenya and Mali were the five top remittances receiving countries in 2011. These countries recorded an average of 52.3 per cent increase in their remittances receipt between 2007 and 2011. In contrast, Benin, Botswana, Cameroun and Malawi recorded a decrease in their remittances. These countries recorded an average of 31.1 per cent decrease in remittances inflow within the period.

The significant increase in remittances flows especially to sub-Saharan Africa over the past decade can be attributed to increased migration of citizens of this region to Europe, North America and East Asia. The phenomenon can also be explained by competition in the remittances market, lower transfer costs, use of formal channels of fund transfer and an improvement in the reporting of data in many developing countries.

As shown in Figure 2, Lesotho and Togo are countries that received the largest remittances as percentage of GDP in 2009, receiving 24.8 percent and 10.3 percent respectively. Cape Verde Guinea Bissau and Senegal received equal percentage (9.1) of their respective GDP as remittances.

Worldwide, remittances have become the second largest capital inflow to developing countries after FDI and before official development assistance (ODA). In some countries such as Nigeria, Sudan, Kenya, and Lesotho among others, remittances have even surpassed the levels of FDI and ODA. In absolute terms, the top 10 remittance receivers in sub-Saharan Africa in 2010 are shown in figure 3.

For many poor countries, remittances are the largest source of external financing. The remittances inflows are significant for many countries, and critical for others, as they constitute sizeable proportion of gross national product (GNP) and export earnings.

However, available evidence shows that in sub-Saharan Africa, the channels of remittances and costs associated with them play critical role on the volume of remittances sent and received, and in determining their contributions to economic development.

\section{Channels and Costs of Remittances}

Various remittance channels are available to migrants. In sub-Saharan Africa, the most popular channels include: Western Union, Money Gram, Nasuba Express, Mobile Money etc. other channels are credit card companies, regular mail service, and financial transfer through banks. The informal channels could be courier services; hand-carried by migrants themselves among other options.

Where the financial sector is inefficient or unavailable especially for recipient household living in the rural areas with no access to financial facility, migrants usually opt for the informal channel while the reverse is the case in areas with strong and trusted financial services. Where the former is the case, "banking the unbanked" program in many developing countries has been found to be the only effective tool toward bringing about a shift in remittance channel used by remittance senders and receivers from informal to formal financial institutions (Inter-America Dialogue 2004).

In Asia and Africa, informal money transfers are very common among low-income group. The 'Hundi' transfer systems are particularly important in Bangladesh and in Sudan. It has been estimated that 85 per cent of Sudanese remittances are routed through the Hawala system partly due to the rapid growth of the volume of 
remittances in the 1990s; services for transferring remittances have actually expanded and diversified (VargasLundius, Lanly, Villarreal and Osorio, 2008).

Costs

World Bank (2006) estimates that the average cost of sending remittance were about 12 per cent of their value in 2004. Cost may range from as low as 0.2 per cent to as high as 20 per cent, depending on the source of transfer, destination, remitted amount and type of remittance channel used.

A comparative study of cost of remittance transfer in 11 low-income countries in Africa Asia and Europe finds that over the last several years, international money transfer companies have been considerably more expensive than commercial banks. The study reports that the average cost of remitting through banks was 7 per cent compared with 12 per cent obtained in transfer companies such as Western Union (Orozco, 2003). Another study of transfer channels between France and Mali, Senegal, Morocco and the Comoros illustrates that the costs of remittances along these corridors are still high. According to the study, it costs between $€ 10$ and $€ 29$ to transfer $€ 300$ from France to these countries (BAFD, 2007).

Cost of remittances in sub-Saharan Africa and elsewhere in the world remains grossly overpriced. Remittances senders are expected to pay other costs such as checking-cashing and conversion fees in addition to the international money transfer fee. Orozco (2004) finds that the cost is higher for remittance receivers in rural areas because of the long distances they have to travel to collect their money. Recipients also often pay handling charges to collect the money or are subjected to unfavourable exchange rates.

According to new data from the Send Money Africa database, Africans pay more to send money home than any other migrant group. Sub-Saharan Africa is the most expensive region to send money to, with average remittance costs reaching 12.4 per cent in 2012. The average cost of sending money to Africa as a whole is almost 12 pe rcent, which is higher than global average of 8.96 per cent, and almost double the cost of sending money to South Asia, which has the world's lowest prices (6.54 per cent).

Governments, intergovernmental organizations and community-based organization are currently collaborating in the campaign for reduction in cost of remittance transfers. As more banks, credit unions, and money transfer companies become involved in the money transfer business and extend their services to migrants' rural communities of origin, remittances cost will likely decrease due to competition.

However, it important that migrant and their recipient communities gain a better understanding of the various options available for remitting and receiving fund. Migrants and recipient communities require unlimited access to local financial institutions, not just for the purpose of affordability, but also because of the increased opportunities to increase their savings and gain access to other financial services such as microcredit (Vargas-Lundius, Lanly, Villarreal and Osorio, 2008).

\section{Empirical Literature}

Remittances to households generally improve their income level and standard of living by making more resources available for food provision and providing enhanced accessibility to education and health care services. Attempts to empirically understand the contribution of remittances to recipient households' welfare viz-a-viz their health and education status have been characterized by inconsistencies. There are divergent and conflicting findings on the contribution of remittances to improving the health and education status of recipients household. While some researchers confirm that health and educational status of children from migrant households tend to improving from remittances, others argue that the impacts are not always positive. Research findings in South Africa show that children from remittance receiving household have higher school enrolment propensities than their peers from non-migrant households (Lu and Treiman 2007).

Through their impact on poverty reduction, remittances enable recipient households to improve their access to quality education and health services. Evidence from household surveys shows that remittances may have reduced the share of poor people in the population by 11 percentage points in Uganda, 6 percentage points in Bangladesh and 5 percentage points in Ghana (Ratha 2007). Cross-country analysis of 78 developing countries also show significant poverty reduction effects of remittances: a 1 per cent increase in per capita official remittances may lead to a 3.5 per cent decline in the share of poor people in the population (Adams and Page 2005).

Analysis of the linkage between remittances and child education in Ecuador with special emphasis on the influences in education supply conditions at the regional level confirm earlier expectation that remittances play favourable role in child education. Results equally highlight the importance of efficient basic education infrastructure to further bolster positive outcomes Benedictis, Calfat and Jara (2010). Also, from 11 Latin American countries, Acosta (2010) finds that remittances have positive effect on education; although, the impact is often restricted to specific groups of the population.

Analysis carried out by Amuedo-Dorantes and Pozo (2009) in Mexico show that international remittances raise healthcare expenditure. Approximately 6 pesos of every 100 peso increment in remittance income are spent on healthcare. Healthcare expenditure responds to remittances by about three times its 
response to other sources of household income. In contrast, a study in Colombia finds no impact of remittances on health expenditure, although, the same study finds a positive and significant impact of international remittances on education, with beneficiary households spending about 10 per cent more of their total expenditure on education than non-beneficiary households (Medina and Cardona 2010).

However, as impressive and instructive as these studies may appear, they are not encompassing: only few are based on the developing countries of sub-Saharan Africa, thus, their findings and policy implications lack regional coverage and usefulness. For instance, the studies by (Lu and Treiman 2007) and (Ratha 2007) concentrate on South Africa and Ghana respectively and dwell majorly on education and poverty impact of remittances. Also, the exclusion of some relevant variables such as education and health expenditure in the analysis reflects the severity of the empirical limitations of these studies. Clearly, there is a need to extend the scope of these studies in terms of geographical coverage and the variables entering the models to see if their findings hold for a larger and broader collection of developing sub-Saharan African countries.

\section{Estimating Remittances Impact on Health and Education Outcomes}

The interaction between remittances and their impact on developing countries has been estimated by many authors on the assumption that remittances are endogenous to health and education outcomes. This assumption follows without the appropriate test for endogeneity. As a departure from this popular practice, this study will first ascertain the presence of endogenous relationship between remittances and health and education outcomes. The test is conducted using the Hausman test for endogeneity. The test model for education outcomes is specified thus:

$$
\begin{gathered}
\mathrm{EDOC}_{\mathrm{it}}=\delta_{1}+\delta_{2} \mathrm{REM}_{\mathrm{it}}+\delta_{3} \mathrm{PREX}_{\mathrm{it}}+\delta_{4} \mathrm{SECEX}_{\mathrm{it}}+\delta_{5} \mathrm{PCI}_{\mathrm{it}}+\delta_{6} \mathrm{HEX}_{\mathrm{it}}+\varepsilon_{\mathrm{it}} \\
\mathrm{REM}_{\mathrm{it}}=\alpha_{1}+\alpha_{2} \mathrm{EDOC}_{\mathrm{it}}+\alpha_{3} \mathrm{PCI}_{\mathrm{it}}+\alpha_{4} \mathrm{RESID}_{\mathrm{it}}+\mu_{\mathrm{it}} \\
\left(\mathrm{i}=1, \ldots, \mathrm{N} ; \mathrm{t}=1, \ldots, \mathrm{T}_{\mathrm{i}}\right)
\end{gathered}
$$

EDOC stands for education outcomes (primary and secondary enrolments); REM stands for remittances; PREX and SECEX represent public primary and secondary education expenditures respectively; PCI represents per capita income; and HEX is public health expenditure per capita; RESID is the residual obtained after estimating equation (a), while $\varepsilon_{\mathrm{it}}$ and $\mu_{\mathrm{it}}$ are the error terms for equations (a) and (b) respectively. EDOC will be measured first by primary education enrolment and then by secondary enrolment. Also, the test model for health outcome is postulated as follows:

$$
\begin{aligned}
& \operatorname{LEXP}_{\text {it }}=\alpha_{1}+\alpha_{2} \text { REM }_{\text {it }}+\alpha_{3} \text { PCI }_{i t}+\alpha_{4} \text { HFCE }_{\text {it }}+\alpha_{5} \text {HEX }_{\text {it }}+\mu_{\text {it }} \\
& \text { REM }_{\text {it }}=\beta_{1}+\beta_{2} \text { LEXPit }+\beta_{3} \text { PCI }_{i t}+\beta_{4} \text { RESID }_{i t}+w_{i t}
\end{aligned}
$$

$$
\left(i=1, \ldots, N ; t=1, \ldots, T_{i}\right)
$$

LEXP is Life expectancy at birth; HCFE is a representative of household final consumption expenditure per capita; RESID is the residual from equation (a); REM, PCI, and HEX are as defined above, while $\mu_{\mathrm{it}}$ and $w_{\mathrm{it}}$ represent the error terms for equation (c) and (d) respectively. We conclude that there is an endogenous relationship between remittances, health and education outcomes if the RESID variable in each model is significant. The results for the tests are presented in tables 1 and 2.

Table 1 presents the results for Hausman test for endogeneity. The RESID variable in Equation (b) is significant, indicating that remittances are actually endogenous to education outcomes. As remittances are influencing education outcomes in both primary and secondary levels, these outcomes on the other hand influence migration and thus, remittances. Equally, results in Table 2 reveal that remittances are endogenous to health outcome, since the RESID variable in Equation (d) is significant. Poor health outcome, say, low life expectancy can force people to migrate to advanced countries partly to enjoy higher life expectancy. To account for this endogeneity, a simultaneous equation model is adopted to estimate the impact of remittance on health and education outcomes.

By increasing the purchasing power of recipient households, remittances enable those households to have unlimited access to education services, especially basic education. Public funding of education is critical to achieving positive outcomes. This is especially true if reasonable allocation is made on primary and secondary education levels Benedictis, Calfat and Jara (2010). Also, healthy living is essential for learning, because it is only when people are healthy that they guarantee improved academic performance (Todaro and Smith, 2010). 
To better understand the impact of remittances on education outcome in sub-Saharan Africa, a model encapsulating the relationship between education outcomes and remittances is specified as follows:

$$
\begin{aligned}
& \operatorname{LogEDOC}_{i t}=\log _{1}+\lambda_{2} \operatorname{LogREM}_{\mathrm{it}}+\lambda_{3} \operatorname{LogPREX}_{\mathrm{it}}+\lambda_{4} \operatorname{LogSECEX}_{\mathrm{it}}+\lambda_{5} \operatorname{LogPCI}_{\mathrm{it}}+ \\
& \lambda_{6} \operatorname{LogHEX}_{\mathrm{it}}+\mathrm{r}_{\mathrm{it}} \\
& \operatorname{LogREM}_{\mathrm{it}}=\log _{1}+\gamma_{2} \operatorname{LogEDOC}_{\mathrm{it}}+\gamma_{3} \operatorname{LogPCI}_{\mathrm{it}}+v_{\mathrm{it}}
\end{aligned}
$$

All variable are as defined above. $r_{\mathrm{it}}$ and $v_{\mathrm{it}}$ are the error terms of equations (e) and (f) respectively. The model assumes that education outcomes are a function of remittances, primary education expenditure, secondary education expenditure, per capita income, and health expenditure. On the other hand, it is equally assumed that remittances depend on the education outcomes and per capita income prevailing in the home country of migrants. Following economic expectations and in line with the findings of other studies, all variable in Equation (e) are expected to be significant and positively signed. On the other hand, variables appearing in Equation (f) are expected to be negative. Improvements in education outcome and per capita income are expected to reduce migration, and thus, remittances. Model 3 will be estimated in two variants: first, education outcome will be measured by primary school enrolment, and then measured by secondary enrolment.

Undoubtedly, remittances have become a significant source of income for recipient households, and have indeed contributed to their improved consumption, including the consumption of healthcare services. Receivers of remittances are expected to improve their health status by spending part of their remittances received on health care services, Acosta (2007). Household consumption expenditure equally impacts on the health status of households, especially if a significant proportion of this expenditure is made on healthenhancing products, (Medina and Cardona, 2010). Public health expenditure also contributes to improving life expectancy by not just making health care services available to consumers, but also reducing their cost. As per capita income improves, people try to adopt a decent life style and afford quality health services. From the ongoing, it is important to develop an econometric model to be used to estimate the impact of remittances on health outcome in sub-Saharan Africa. The proposed model is specified as follows:

$$
\begin{aligned}
& \operatorname{LogLEXP} \mathrm{it}_{\text {it }}=\log _{1}+\pi_{2} \operatorname{LogREM}_{\text {it }}+\pi_{3} \operatorname{LogPCI}_{\text {it }}+\pi_{4} \operatorname{LogHFCE}_{\text {it }}+\pi_{5} \operatorname{LogHEX}_{\text {it }}+\rho_{\text {it }} \\
& \operatorname{LogREM}_{\mathrm{it}}=\log _{1}+\mathrm{z}_{2} \operatorname{LogLEXPit}+\mathrm{z}_{3} \operatorname{LogPCI}_{\mathrm{it}}+\omega_{\mathrm{it}}
\end{aligned}
$$

$$
\left(\mathrm{i}=1, \ldots, \mathrm{N} ; \mathrm{t}=1, \ldots, \mathrm{T}_{\mathrm{i}}\right)
$$

All variable are as defined above. $\rho_{\text {it }}$ and $\omega_{\text {it }}$ are the error terms of equations $(\mathrm{g})$ and $(\mathrm{h})$ respectively. The model hypothesizes that health outcome in country $i$ in time $t$ depends on remittances, per capita income, household final consumption expenditure and health expenditure in that country at that same time. Conversely, remittances are equally assumed to depend on health outcomes in country $i$ in time t. The independent variables in Equation (g) are expected to have a positive and significantly impact on health outcome, while those in Equation (h) are expected to be negative, judging from conventional economic wisdom.

Both models 3 and 4 will first be estimated without dummy ${ }^{1}$, and then re-estimated with dummy variables. The essence of this approach is to check if there are differences in the impact of the explanatory variables on the dependent variables in the sampled countries as a group, and as individual countries. The dummy variables are determined as follows: REM dummy $=1$ for REM greater than or equal to US $\$ 275$ million; 0 otherwise. PREX dummy $=1$ for PREX greater than or equal to 50 per cent; 0 otherwise. SECEX dummy $=1$ for SECEX greater than or equal to 30 per cent; 0 otherwise. PCI dummy $=1$ for PCI greater than or equal to US $\$ 2000 ; 0$ otherwise. HEX dummy $=1$ for HEX greater than or equal to US $\$ 60 ; 0$ otherwise; and $\mathrm{HFCE}$ dummy $=1$ for HFCE greater or equal to US $\$ 376 ; 0$ otherwise.

\section{The Data Set}

All data are from the World Bank's African Development Indicator. Life expectancy at birth indicates the number of years a newborn infant would live if prevailing patterns of mortality at the time of its birth were to stay the same throughout its life. Primary and secondary education expenditure is the total public expenditure per student in primary and secondary education respectively as percentage of total public education expenditure;

\footnotetext{
${ }^{1}$ The dummy variable benchmarks are the regional averages of their respective variables.
} 
public education expenditure (current and capital) includes government spending on educational institutions (both public and private), education administration as well as subsidies for private entities (students/households and other private entities). GDP per capita is based on purchasing power parity (PPP). PPP GDP is gross domestic product (GDP) converted to international dollars using purchasing power parity rates. An international dollar has the same purchasing power over GDP as a U.S. dollar has in the United States. Primary and secondary enrolments are the total enrollment in primary and secondary education respectively, regardless of age.

The descriptive statistics presented in Table 3 show that on the average, our countries of interest enrolled 2337483 pupils and 200057 students in their primary and secondary schools respectively within the period covered by the study. However, the standard deviations of these variables indicate a massive fluctuation in their values. Similarly, the average values of per capita income and health expenditure per capita of US \$2465 and US $\$ 90$ respectively also deviate significantly from their mean values. In contrast, primary and secondary expenditure average approximately 47 per cent and 29 per cent respectively, and are relatively stable.

For most of the countries sampled, life expectancy is reasonably stable at an average of 54 years. As for household final consumption expenditure per capita, its average value of US $\$ 344$ is largely unstable.

\section{Estimation Results}

In each table, results are shown first without, and then with, country dummies. Since all of the variables are estimated in log terms, the results can be interpreted as elasticities of health and education outcomes with respect to the relevant variables. The rank and order conditions for identifying a simultaneous equation model confirm that the models are over identified, leading to the adoption of a Two Stage Least Square (2SLS) estimation technique.

Table 4 presents the first stage 2SLS regression results. Results suggest that remittances significantly and positively impact on both primary and secondary education outcomes in sub-Saharan Africa. This implies that as households receive remittances, they are able to send their children to school, and the more remittance they receive, the higher the motivation to substitute education for farm work or other family income-earning activities that their children are used for. Equation (1) presents the result when dummy variables are not included. When education outcome is measured by primary education, the results shows that a 10 per cent increase in remittances increases primary education outcome by an average of 4.2 per cent. Contrary to expectation, expenditures on primary and secondary levels of education do not have any significant impact on primary education outcome. It does appear that households are not motivated to send their children to school by the level of public expenditure on either primary or secondary education. The explanation to this may be because the expenditure has no direct contribution to household income. Even where primary education is tuition-free, households will prefer to engage their children to income-earning activities to boost family income but will be willing to release them for school when there are alternative sources of increasing family income, such as remittances. Income per capita and public health expenditure per capita are rightly signed and statistically significant, implying a positive impact on primary education. There exists a one-on-one relationship between primary education outcome and per capita income. For any 1 per cent increase in per capita income, primary education outcome increases by 1 per cent on the average. Similarly, for a 1 per cent increase in public health expenditure per capita, primary education outcome records an average of 1.58 per cent increase.

Equation (2) shows the results after correcting for country differences using dummy variables. Migrant remittances show an insignificant association with primary education outcome. This implies that remittances could be significant on regional analysis, that is, in sub-Saharan Africa as a region, but may not be significant on individual country basis, and this may be explained by the magnitude of remittances received by individual countries. Even the remittance dummy is also insignificant. This means that countries that receive annual remittances below US $\$ 275$ million will record zero impact of such remittances on primary education. Coincidentally, over 60 per cent of sampled countries and over 70 per cent of all countries in the region receive annual remittances below this regional benchmark. Conversely, primary education expenditure, per capita income and per capita public health expenditure all share positive and significant relationship with primary education outcome. For any 1 per cent increase in primary education expenditure, per capita income, and per capita public health expenditure, primary education outcome will record an average increase of 5.13 per cent, 0.96 per cent and 1.55 per cent respectively. The primary expenditure dummy is significant, indicating that countries that spend at least 50 per cent of their total education expenditure on primary education will record a more impressive outcome than those that spends below that regional average. In fact, for any 1 percentage point increase in primary education expenditure over 50 per cent, primary education outcome is bound to increase by 1.91 percentage points. This finding is interesting and reinforces the need for adequate funding of primary education in sub-Saharan Africa countries. 
On secondary education outcome, the estimates from equation (3) reveal that migrant remittances positively and significantly impacts on secondary education outcome. Increasing remittances by 10 per cent will on the average, increase secondary education outcome by 8.8 per cent. Primary education expenditures is equally significant and exerts positive impact on secondary education outcome. For any 1 per cent increase in primary education expenditure, secondary education outcome goes up by an average of 4.92 per cent. This is because primary education is the preparation ground for secondary education, so much so that as more investments are made on the former, more people are prepared to enroll to the latter. Conversely, secondary education expenditure is statistically insignificantly correlated with secondary education outcome. This result is against conventional knowledge that higher funding of secondary education guarantees higher quality of education services and improves chances of enrolment for potential students, and highlights the need for prudent utilization of the budgetary allocations meant for secondary education. Equation (4) presents the results after accounting for country heterogeneity. Results show that remittances still remain a significant factor explaining secondary education outcome in sub-Saharan Africa; remittances now account for 1.89 per cent increase in secondary education outcome if the former increases by 1 per cent. The dummies for remittances and secondary education expenditure are all significant, statistically speaking. This reveals that countries that receive annual remittances of at least US \$275 million and spend at least 30 per cent of their total education budget on secondary education have greater prospects of increasing their secondary education outcome. Table 5 shows the second stage of the 2SLS results. Results show that neither primary nor secondary education outcome significantly influences remittances. Indeed, remittances may be endogenous to health and education outcomes, such relationship are not usually significant. However, health expenditure per capita dummy is found to be significantly associated with remittances.

It is important to note that, although primary education expenditure impacts significantly on secondary education outcome, secondary education expenditure do not in turn impact on primary education outcome. This highlights the fact that achieving functional literacy rate in sub-Saharan African countries is dependent on increased funding of primary education.

The regression results in Table 6 reveal interesting findings on how migrant remittances impact on health status of the citizens of remittance receiving countries. Equation (1) shows the first stage without dummy. Results show that health outcome will increase by 1.2 per cent on the average following a 10 per cent increase on migrant remittances. This implies that better health outcome could be recorded by ensuring productive utilization of remittances. Public health expenditure per capita and household per capita consumption expenditure also exhibit positive and significant relationship with health outcome. Increasing public health expenditure per capita by 10 per cent will stimulate health outcome by 0.5 per cent on the average. Similarly, increasing household per capita consumption expenditure by the same magnitude will yield an average significant impact of 0.6 per cent on health outcome. This implies that to improve health outcome, health expenditure should be enhanced because increasing health expenditure leads to improved access to quality health care services and consequently improved health status. This argument is also true of per capita household consumption expenditure. Increasing household income leads to increased household spending, especially spending in health care services and other welfare-enhancing consumption expenditures. These lead to improved longevity. Equation (2) presents the results when dummy variables are introduced. A positive significant impact of remittances on health outcome is found. Increasing remittances by 10 per cent can cause health outcome to increase by up to 0.4 per cent on the average.

Per capita income is found to be significant and causes up to 0.2 per cent increase in health outcome for any 10 per cent increase it records. However, the per capita income dummy is not significant, implying no difference in impact between countries with per capita income of US $\$ 2,000$ or above and those with income per capita below US $\$ 2,000$. Although public health expenditure per capita and household consumption expenditure per capita now appear insignificant, their dummy variables are significant. The implication of this is that countries with household per capita consumption expenditure of US \$376 or above and those with per capita public health expenditure of US $\$ 60$ or above are more likely to have these variables impact on their health outcome than those with expenditures below these regional averages.

Equations (3) and (4) present the second stage result where the dependent variable is remittances, without and with dummy respectively. Without dummy, health outcome is insignificant correlated with remittances. When dummies are included, a negative significant impact of health outcome on remittances is found.

\section{Policy Recommendations}

After extensive empirical analysis, the following policy recommendations are considered relevant for ensuring a sustainable improvement in health and education outcomes in sub-Saharan Africa.

Stakeholders in the remittance transfer corridors should ensure that the cost of remittances is significantly reduced to allow for increased inflow of remittances into sub-Saharan Africa. This is important 
given that increased remittance inflow yields better education and health outcomes. Bringing remittances transfer prices down to 5 per cent from the current average of 12.4 per cent, which is what the G8 and G20 are targeting by 2014, would put US $\$ 4$ billion back in the pockets of Africa's migrants and their families.

The role of technological innovations in financial service delivery is important in reducing the cost of remittances. These new technologies allow migrants and their families at home to send and receive money at reasonable convenience. A regulatory environment that encourages competition among remittance service providers not only gives migrants more choices, it can also help bring down prices. Migrants can also benefit from more transparent information on remittances services because it gives them the resources they need to make informed decisions.

In order to achieve the second goal of the millennium Development Goals (MDGs) - achieve universal primary education, that is, ensure that all boys and girls complete a full course of primary schooling, and improved longevity - opportunities to migrate and remit fund should be created. This can be achieved by building bilateral relationships with the advanced countries of the West to ensure easy migration of sub-Saharan Africa's job seekers to these countries and relaxing the unfair labour legislations in those countries to allow better job opportunities for African migrants. Also appropriate policy framework should be put in place to enable migrants remit significant proportion of their income to their home countries.

Governments of sub-Saharan Africa countries must make the funding of basic education a development priority. Sub-Saharan African governments must ensure that at least 50 per cent of their total education expenditure is allotted to primary education. Equally, expenditure in secondary education should not fall below 30 per cent of total education expenditure. This will ensure that opportunities are created for people to further their education beyond the primary level. As a social service, education investments are not profit-oriented and as a result, are not attractive to private investors. This makes the funding of primary and secondary education an exclusive responsibility of the government. Therefore, governments should explore all possible funding options available, which may include private public partnership and mobilizing external funding sources through engaging the financial and technical support of international development organizations.

Ensuring adequate funding of the primary health sub-sector will ensure adequate provision of health care services, especially at the grassroots. The benefits of this to the citizens are that it does not only guarantee their healthy living, but also improves on their educational performance, because it only when people are health that they go to school and perform creditably.

The positive influence of per capita income on health and education outcomes in sub-Saharan African countries calls for the formulation and implementation of appropriate policy framework that will enhance income-earning opportunities. This will stimulate household annual consumption expenditure per capita in health and education to at least US $\$ 376$, thereby improving the health and education status of the citizens of the region.

\section{Summary}

The developing nature of Sub-Saharan African countries highlights that resources are scarce, unemployment very high and income very low. These make it necessary for Africans to migrate out of their home countries as a survival strategy against poverty. Remittances from international migrants have continued to constitute the second largest source of external financial inflow after FDI, and are now used by receivers to augment household income. However, the contributions of these remittances to the improvements in education and health status of receiving countries have remained uncertain. This work is intended to investigate the impact of international migrant remittances on health and education outcomes of sub-Saharan African countries. Evidence from data analysis reveals a positive and significant impact of remittances on health and education, reinforcing the argument that remittances can be effective resource in achieving MDGs numbers 2, 4, and 5 . Equally, Per capita income, household per capita consumption, health and education expenditures are found to exhibit positive and significant association with health and education outcomes of countries sampled. Policy implications are that policy makers must develop appropriate incentive for migrants to remit, especially policies influencing the costs and channels of remittances. Also, increasing health and education expenditures as well as providing income-earning opportunities to boost household per-capita income and consumption are other policy options that should be explored.

\section{References}

[1]. Acosta, P. Fajnzylber P. and J. Humberto Lopez (2007) "The Impact of Remittances on Poverty and Human Capital: Evidence from Latin American Household Surveys" World Bank Policy Research Working Paper 4247, Washington D.C.: The World Bank.

[2]. Adams, R.H. (1993). "Economic and Demographic Determinants of International Migration in Rural Egypt". Journal of Development Studies 30, No. 1. Washington D.C.: International Food Policy Research Institute (IFPRI).

[3]. - 2005. Remittances, Household Expenditure and Investment in Guatemala. World Bank Policy Research Working Paper No. 3532. Washington D.C.: World Bank.

[4]. - 2006. Remittances and Poverty in Ghana. World Bank Policy Research Working Paper No. 3838. Washington D.C.: World Bank. 
[5]. Adams, R.H and Page, J. (2005). "International Migration, Remittances and Poverty in Developing Countries". World Bank Policy Research Working Paper No. 3179. Washington D.C.: World Bank.

[6]. Aggarwal, R. Demirguç-Kunt, A. and M.S.M. Peria, (2006), "Do workers' Remittances Promote Financial Development?" Washington, D.C.: World Bank.

[7]. Amuedo-Dorantes, C. And S. Pozo (2009) "New Evidence on the Role of Remittances on Health Care Expenditures by Mexican Households" IZA Discussion Paper No. 4617 No. 4617, Germany: Institute for the Study of Labor.

[8]. BAfD (2007). Les Transferts de Fonds de Migrants, un Enjeu de Developpment: LesComores, Mali, Maroc, Sénégal. Rapport Provisoire, October. Abidjan, Côte d'Ivoire: African Development Bank.

[9]. Benedictis, G. Calfat, G. And K. Jara (2010) “Assessing the Impact of Remittances on Child Education in Ecuador: The Role of Educational Supply Constraints" Institute of Development Policy and Management Working Paper / 2010.06, Belgium: University of Antwerp.

[10]. Inter-American Dialogue. (2004). All in the Family: Latin America's Most Important International Financial Flow. Report of the Inter-American Dialogue Task Force on Remittances. Washington, D.C.

[11]. Mara, I. et al (2012) "Analysis of Literature on the Effects of Remittances on Education and Health of Family Members Left Behind”. Regional Research Promotion Programme, Western Balkans.

[12]. Medina. C. And L. Cardona (2010) "The Effects of Remittances on Household Consumption, Education Attendance and Living Standards: The Case of Colombia" Lecturas De Economía. 72 (Enero-Junio 2010), Pp. 11-43.

[13]. Mora, J., \& Taylor, J. E. (2005). Determinants of International Migration: Disentangling Individual, Household and Community Effects. Unpublished Manuscript. Department of Agricultural Economics, University of California, Davis, USA.

[14]. Orozco, M. (2003). Worker Remittances in an International Scope. Report of Inter-American Dialogue. Washington, D.C.: USAID.

[15]. _ (2004) The Remittance Marketplace: Prices, Policy and Financial Institutions. Washington, D.C.: Pew Hispani Center, http://pewhispanic.org/reports/report.php?

[16]. Passel, J., Capps, R., Fix, M. (2004). Undocumented Immigrants: Facts and Figures. Unpublished Manuscript. Urban Institute, Washington, DC.

[17]. Ratha, D. (2004). Enhancing the Developmental Effect of Workers' Remittances to Developing Countries. In Global Development Finance (Pp. 169-173). Washington, DC: World Bank.

[18]. (2006) Economic Implications of Remittances and Migration, Global Consumer Money Transfer Conference, October 30, London: World Bank.

[19]. (2007a). "Leveraging Remittances for Development", MPI Policy Brief. Washington, D.C.: Migration Policy $\overline{\text { Institute. }}$

[20]. (2007b). "International Remittances and the Household: Analysis and Review of Global Evidence". World Bank Policy Research Working Paper No. 4116. Washington D.C.: World Bank.

[21]. Todaro and Smith, (2009) Economic Development, $10^{\text {th }}$ edition, England: Pearson Educational Limited.

[22]. Vargas-Lundius R. Lanly G. Villarreal M. And M. Osorio, (2008) "International Migration, Remittances and Development", Rome: International Fund for Agricultural Development (IFAD).

[23]. Vogler, M., \& Rotte, R. (2000). The Effects of Development on Migration: Theoretical Issues and New Empirical Evidence. Journal of Population Economics, 13, 485-505.

[24]. World Bank (2006). Global Economic Prospects 2006: Economic Implications of Remittances and Migration. Washington, D.C.: World Bank.

[25]. _ _ (2011) Migration and Remittances Factbook, Migration and Remittances Unit, Washington D.C.: World Bank.

[26]. (2012) African Development Indicator, Washington D.C.: World Bank. Available at: data.worldbank.org.

[27]. Yao, L. and Treiman, D.J. (2007). "Effect of Labor Migration and Remittances on Children's Education among Blacks in South Africa”. CCPR Working Paper 001-97, California Center for Population Research, Los Angeles: University Of California.

Table1: Hausman Test for Endogeneity between Remittances and Education Outcomes

\begin{tabular}{|c|c|c|c|}
\hline \multirow[t]{2}{*}{ Variables } & \multicolumn{2}{|c|}{ Primary Education Outcome } & Secondary Education Outcome \\
\hline & First Stage & Second Stage $^{2}$ & Second Stage $^{4}$ \\
\hline REM & $2.36(1.107)$ & \multicolumn{2}{|r|}{$-73.35(-0.714)$} \\
\hline PREX & $-11812(-0.581)$ & \multicolumn{2}{|r|}{$2460(0.765)$} \\
\hline SECEX & $3226(0.137)$ & \multicolumn{2}{|r|}{$1893(0.940)$} \\
\hline PCI & $-1310(-3.208)^{*}$ & $0.0038(0.27)$ & $70.24(0.865)-0.0031(-0$ \\
\hline EDOC & & $0.0002(4.22)^{*}$ & $0.0027(2.99)^{* *}$ \\
\hline RESID & & $-0.0002(-2.30) * *$ & $0.0027(3.08)^{*}$ \\
\hline HEX & $32339(3.034)^{*}$ & \multicolumn{2}{|r|}{$-1773(-0.835)$} \\
\hline $\mathrm{C}$ & $2520814(2.18)^{* *}$ & $-153.4(-2.08)^{* *}$ & $817.4(3.18)^{*}$ \\
\hline $\mathrm{R}^{2}$ & 0.18 & 0.52 & $0.04 \quad 0.30$ \\
\hline
\end{tabular}

${ }^{1}$ Dependent variable $=$ Primary enrolment; ${ }^{2}$ and ${ }^{4}$ Dependent Variable $=$ Remittances; ${ }^{3}$ Dependent variable $=$ Secondary enrolment; * Significant at 1 percent; ** Significant at 5 percent;

Table 2: Hausman Test for Endogeneity between Remittances and Health Outcome

\begin{tabular}{lcc} 
Variables & First Stage $^{1}$ & Second Stage $^{2}$ \\
\hline REM & $0.003(2.295)^{* *}$ & \\
PCI & $-0.001(-1.111)$ & $0.038(1.34)$ \\
LEXP & & $160.89(2.13)^{* *}$
\end{tabular}




\begin{tabular}{|c|c|c|c|c|c|c|c|}
\hline \multicolumn{6}{|l|}{ RESID } & \multicolumn{2}{|c|}{$-160.89(-2.24) * *$} \\
\hline HEX & & \multicolumn{4}{|c|}{$0.004(0.342)$} & & \\
\hline HFCE & & \multicolumn{4}{|c|}{$0.004(1.791)^{* * *}$} & \\
\hline $\mathrm{C}$ & & \multicolumn{4}{|c|}{$52.86(44.93) *$} & -8447( & $2.09)^{* *}$ \\
\hline $\mathrm{R}^{2}$ & & \multicolumn{4}{|c|}{0.15} & & 0.37 \\
\hline \multicolumn{8}{|c|}{$\begin{array}{l}{ }^{\mathrm{T}} \text { Dependent Variable }=\text { Life Expectancy } \\
{ }^{2} \text { Dependent Variable }=\text { Remittances }\end{array}$} \\
\hline \multicolumn{8}{|c|}{ Table 3: Descriptive Statistics } \\
\hline & & Mean & Media & Maximum & Minimun & & Std. Dev \\
\hline Primary Expenditure & & 46.72 & 45.9 & 71.2 & & 0.00 & 15.97 \\
\hline Secondary Expenditure & 28.76 & 29.00 & 54.10 & 0.00 & 11.97 & & \\
\hline Per Capita Income & & 2464 & 1263 & 13146 & 7.70 & 3246 & \\
\hline Health Expenditure & & 90.23 & 44.10 & 521.0 & 0.00 & 138.1 & \\
\hline H/Hold Final Cons. & & 562.8 & 272.0 & 13337 & 0.00 & 1797 & \\
\hline Life Expectancy & 53.63 & 53.10 & 64.00 & 46.7 & 3.72 & & \\
\hline Secondary Enrolment & & 200057 & 26269 & 13568180.00 & 39496 & & \\
\hline Primary Enrolment & & 2337483 & 156125 & 83746 & 80.00 & 241777 & \\
\hline Remittances & & 274.94 & 102 & 1478 & & 0.00 & 378.25 \\
\hline
\end{tabular}

Source: Authors'

Table 4: First Stage 2SLS Estimates of the Impact of Remittances on Education Outcomes

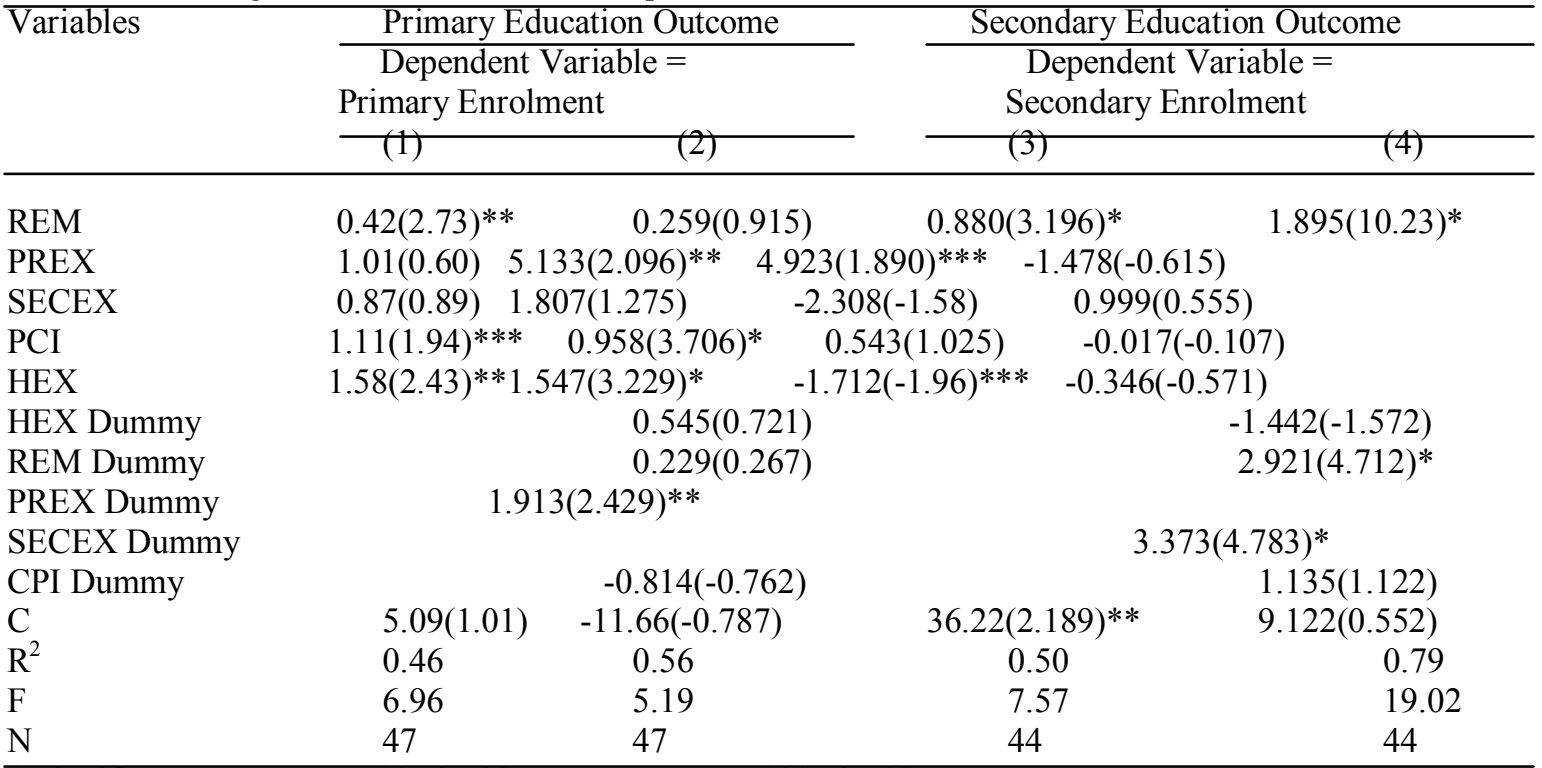

* Significant at 1 percent; ** Significant at 5 percent; *** Significant at 10 percent.

Source: Authors'

Table 5: Second Stage 2SLS Estimates of the Impact of Remittances on Education Outcomes

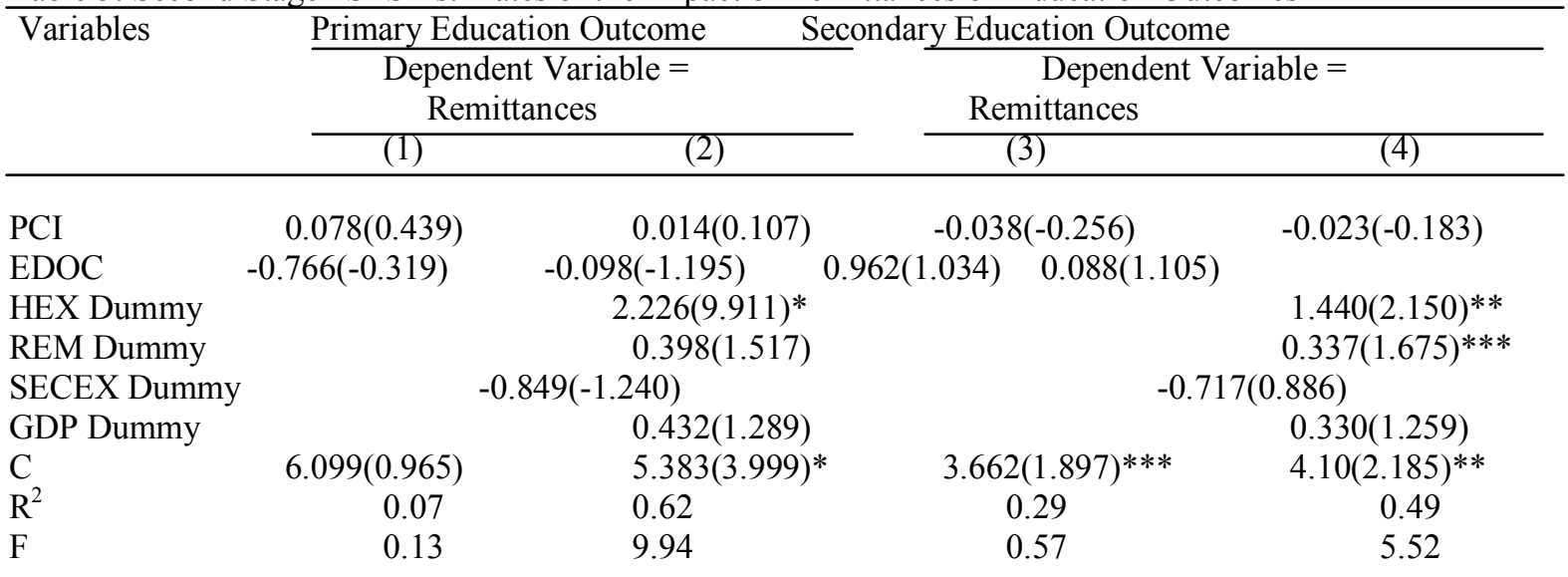




\begin{tabular}{|c|c|c|c|c|}
\hline \multicolumn{5}{|c|}{44} \\
\hline \multicolumn{5}{|c|}{$\begin{array}{l}\text { * Significant at } 1 \text { percent; }{ }^{* *} \text { Significant at } 5 \text { percent; }{ }^{* * *} \text { Significant at } 10 \text { percent. } \\
\text { Source: Authors' }\end{array}$} \\
\hline \multirow{5}{*}{$\frac{\text { Table 6: } 2 \mathrm{SI}}{\text { Variables }}$} & \multirow{4}{*}{\multicolumn{2}{|c|}{$\begin{array}{l}\text { of the Impact of Remittances on } \mathrm{He} \\
\text { First Stage } \\
\text { Dependent Variable }= \\
\text { Life Expectancy } \\
\end{array}$}} & \multirow{4}{*}{\multicolumn{2}{|c|}{$\begin{array}{l}\text { Outcomes } \\
\text { Second Stage } \\
\text { Dependent Variable }= \\
\text { Remittances } \\
\end{array}$}} \\
\hline & & & & \\
\hline & & & & \\
\hline & & & & \\
\hline & (1) & (2) & (3) & (4) \\
\hline$\overline{R E M}$ & $0.015(1.71)^{* * *}$ & $0.038(4.74)^{*}$ & \multirow{2}{*}{\multicolumn{2}{|c|}{$000(1-70) * * *$}} \\
\hline PCI & $0.015(1.35)$ & $0.016(5.72)^{*}$ & $0.09(1.79)^{* * *}$ & \\
\hline LEXP & & & \multicolumn{2}{|c|}{$3.02(0.09) \quad-3.169(-2.59) * *$} \\
\hline HEX & $0.048(3.24)^{*}$ & $-0.156(-1.27)$ & & \\
\hline HFCE & $0.061(2.27)^{* *}$ & $0.012(0.45)$ & \\
\hline REM dummy & & $0.112(5.46)^{*}$ & \multicolumn{2}{|c|}{$0.303(0.96)$} \\
\hline PCI dummy & & $0.015(0.75)$ & \multicolumn{2}{|c|}{$\begin{array}{r}2.128(6.19)^{*} \\
0.343(09)\end{array}$} \\
\hline HEX dummy & & $0.127(5.96)^{*}$ & \multirow{2}{*}{\multicolumn{2}{|c|}{$\begin{array}{l}0.343(0.89) \\
0.621(1.68) * * *\end{array}$}} \\
\hline HFCE dummy & & $0.088(3.62) *$ & & \\
\hline $\mathrm{C}$ & $3.625(17.96)^{*}$ & $4.0(29.49)^{*}$ & $-0.29(-0.01)$ & $16.41(3.32)^{*}$ \\
\hline $\mathrm{R}^{2}$ & 0.27 & 0.83 & 0.2 & 0.61 \\
\hline $\mathrm{F}$ & 2.79 & 15.64 & 0.3 & 6.57 \\
\hline $\mathrm{N}$ & 35 & 35 & 32 & 32 \\
\hline
\end{tabular}

* Significant at 1 percent; $* *$ Significant at 5 percent; *** Significant at 10 percent.

Source: Authors' 